\title{
Reisolation of Staphylococcus aureus from bovine milk following experimental inoculation is influenced by fat percentage and specific immunoglobulin $\mathbf{G}_{1}$ titer in milk
}

\author{
E. M. Boerhout, ${ }^{*} \dagger^{1}$ A. P. Koets, $₫ \S$ J. C. M. Vernooij,§ T. G. T. Mols-Vorstermans, ${ }^{*}$ P. J. M. Nuijten, ${ }^{*}$ \\ V. P. M. G. Rutten, †\# J. J. E. Bijlsma, $\|^{2}$ and S. W. F. Eisenberg $\S^{2}$ \\ ${ }^{*}$ Ruminants Research and Development, MSD Animal Health, Wim de Körverstraat 35, 5830 AA Boxmeer, the Netherlands \\ †Department of Infectious Diseases and Immunology, Faculty of Veterinary Medicine, Utrecht University, Yalelaan 1, 3584 CL Utrecht, \\ the Netherlands \\ ‡Department of Bacteriology and TSE, Central Veterinary Institute part of Wageningen UR, Edelhertweg 15, PO Box 65, 8200 AB Lelystad, \\ the Netherlands \\ $\S$ Department of Farm Animal Health, Faculty of Veterinary Medicine, Utrecht University, Yalelaan 7, 3584 CL Utrecht, the Netherlands \\ \#Department of Veterinary Tropical Diseases, Faculty of Veterinary Science, University of Pretoria, Private Bag X04, Onderstepoort 0110, \\ South Africa \\ IIDiscovery and Technology, MSD Animal Health, Wim de Körverstraat 35, 5830 AA Boxmeer, the Netherlands
}

\begin{abstract}
The associations of management parameters, herd characteristics, and individual cow factors with bovine mastitis have been subject of many studies. The present study aimed to evaluate the association between milk composition parameters, including fat, protein, lactose, urea, and specific immunoglobulin levels, at the time of experimental bacterial inoculation of the mammary gland and subsequent shedding dynamics of Staphylococcus aureus. Sixty-eight cows were experimentally infected with $S$. aureus and closely monitored for 3 wk. Mixed model analyses were used to determine the influence of management and herd characteristics (farm and experimental group), individual cow factors (days in milk, milk yield, and quarter position), and a challengerelated parameter (inoculation dose) in combination with either the milk components fat, protein, lactose and urea, or the $S$. aureus-specific antibody isotype titers at the time of bacterial inoculation, on the number of $S$. aureus reisolated from milk after inoculation. A positive association was observed between the milk fat percentage and the number of $S$. aureus reisolated from quarter milk, and a negative relationship between the $S$. aureusspecific $\operatorname{IgG}_{1}$ titer in milk and the number of $S$. aureus. These findings should be considered in the development of a vaccine against $S$. aureus-induced bovine mastitis.
\end{abstract}

Key words: bovine mastitis, Staphylococcus aureus, milk fat percentage, specific immunoglobulin $G_{1}$ titer

Received November 16, 2015.

Accepted February 9, 2016.

${ }^{1}$ Corresponding author: eveline.boerhout@merck.com emboerhout@gmail.com

${ }^{2}$ Both authors contributed equally to this work.

\section{INTRODUCTION}

Mastitis is a major concern in the modern dairy industry because it is the most costly infectious disease due to milk losses, the need for veterinary interventions, and early culling of cows. The risks associated with increasing antibiotic resistance due to the current treatment of mastitis with antibiotics call for preventive strategies rather than treatment. Apart from management parameters and hygiene procedures, exploring the potential of vaccination as a preventive strategy is an ongoing effort (Tollersrud et al., 2001; Pellegrino et al., 2010; Leitner et al., 2011). For evaluation of potential vaccine candidates and vaccines, experimentally induced mastitis is often used as a model system (Middleton et al., 2006; Cui et al., 2010). However, in experimental infection studies, it has been observed that inoculation of bacteria leads to highly variable bacterial shedding dynamics between cows and even between quarters of the same cow, indicating the presence of cow- or quarter-dependent susceptibility (Schukken et al., 1999; Tollersrud et al., 2006). A substantial amount of research has been dedicated to the identification of individual cow factors and their association with mastitis under field conditions. Frequently studied parameters include farm, herd, milking systems, season, parity, lactation stage, quarter position and physiology, and history of mastitis (Zadoks et al., 2001; Park et al., 2007; Steeneveld et al., 2008; Krömker et al., 2012; Leelahapongsathon et al., 2014; Yang et al., 2015). Other studies have focused on the SCC and, more in depth, the different cell types observed in milk pre- and postinfection (Schukken et al., 1999; Bannerman et al., 2004; Pilla et al., 2012, 2013; Reyher et al., 2013). 
In this study, we analyzed the association between milk composition, including immunoglobulin levels, at the time of experimental bacterial inoculation of the mammary gland and the bacterial shedding dynamics thereafter using data from cows of multiple independent challenge experiments. Measuring the concentrations of fat, protein, lactose, and urea in milk is part of the routine screening of all cows on farms in many management systems. If milk components influence the growth characteristics of mastitis-inducing pathogens, they can contribute to susceptibility or resistance to mastitis, and cows at risk may be quickly identified through these screenings. Although immunoglobulin levels are usually not measured on a regular basis, associations between bacteria-specific immunoglobulin isotype levels and susceptibility or resistance to mastitis are of interest in the development of a vaccine against mastitis. For vaccine efficacy testing, knowledge about the contribution of these factors to a cow's susceptibility or resistance to mastitis will enable defined animal selection and group stratification, which may contribute to a robust and reproducible animal model. The present study specifically focused on experimentally induced intramammary infections with Staphylococcus aureus, one of the main mastitis-causing pathogens in bovines. The $S$. aureus Newbould strain was used for experimental inoculations because this strain is strongly associated with, and known to be well adapted to, the bovine host (Smith et al., 2005; Bouchard et al., 2012). Intramammary infections with $S$. aureus are often subclinical and persistent in nature. Staphylococcus aureus Newbould has been shown to typically induce subclinical, persistent, and in most cases reproducible infections (Schukken et al., 1999; Shkreta et al., 2004; Middleton et al., 2006). Furthermore, this strain possesses biofilm-associated genes, colonization factors, and genes encoding secreted toxins (Peton et al., 2014), which are target proteins in various vaccine development studies (Nordhaug et al., 1994; Camussone et al., 2014).

\section{MATERIALS AND METHODS}

\section{Animals}

Data obtained from 68 clinically healthy, first-lactation Holstein Frisian cows purchased from commercial dairy herds were used in this study. Cows were enrolled in 7 independent challenge experiments between October 2012 and July 2014. Selection of the cows was based on similarity in age $(2.5 \mathrm{yr} \pm 3 \mathrm{mo})$, low $\mathrm{SCC}(<100,000$ cells $/ \mathrm{mL}$ ), and no history of mastitis. Cows were housed in freestall barns at 1 of 2 experimental animal facilities of MSD-Animal Health (farms A and B; Boxmeer area, the Netherlands), and fed a mixed ration containing maize silage, grass clover silage concentrate, and minerals (For Farmers Hendrix, Lochem, the Netherlands) according to their requirements (Dutch feeding tables; CVB, 2012). Water was supplied ad libitum. Before experimental intramammary $S$. aureus inoculation, cows were allowed an acclimatization period of at least $2 \mathrm{mo}$ and were kept under regular supervision of a veterinarian. Cows were milked twice a day at 12-h intervals using a traditional pipeline milking system. Premilking teat disinfection was practiced routinely with $70 \%$ alcohol and postmilking teat disinfection with a $0.5 \%$ iodine disinfectant. Daily milk yield was recorded throughout the study. The design of these studies was approved by an independent ethical committee. The experiment was performed in accordance with European Community guidelines and national laws on animal experiments.

\section{Bacterial Strain}

Animals were experimentally infected with the $S$. aureus Newbould 305 strain (ATCC 29740). A freeze-dried stock of these bacteria was resuspended in sterile water and plated onto sheep blood agar plates (BioTrading, Mijdrecht, the Netherlands). Following overnight incubation at $37^{\circ} \mathrm{C}$, bacteria were cultured in trypticase soy broth (BioTrading) for $5 \mathrm{~h}$ at $37^{\circ} \mathrm{C}$. Before intramammary inoculation, bacteria were washed twice with $0.9 \%$ physiological saline and, following microscopic counting, diluted to the desired concentration in $0.9 \%$ physiological saline. Cultures were plated onto sheep blood agar plates and, following an incubation of 16 to $24 \mathrm{~h}$ at $37^{\circ} \mathrm{C}$ and $5 \% \mathrm{CO}_{2}$, numbers of colony-forming units were counted to determine the actual number of viable cells per inoculation dose.

\section{Experimental Intramammary Inoculation}

Animals were experimentally infected by administering $1 \mathrm{~mL}$ of inoculum containing 2.41 to $2.93 \log _{10} \mathrm{cfu}$ of $S$. aureus into the teat streak canal of 2 mammary quarters per cow, and the other 2 quarters were left untreated. Inoculation was performed 1 to $3 \mathrm{~h}$ after the morning milking using a sterile plastic 5 -mL syringe and individual plastic infusion cannulas (Bovivet Animal Healthcare, Bengaluru, Karnataka, India). Before inoculation, teat ends were disinfected with $70 \%$ alcohol. Generally, both front quarters were experimentally inoculated and the rear quarters were left untreated. Only quarters clear of major mastitis-causing pathogens, free of infection by other bacteria, and with an SCC $<100,000$ cells $/ \mathrm{mL}$ at 2 samplings within $7 \mathrm{~d}$ before inoculation were included in the study. When a front quarter did not meet these criteria, a rear quarter was inoculated. The 2 inoculated quarters were always 
located on opposite sites (left and right) of the mammary gland. Experimental infections were conducted on 7 groups of animals $(\mathrm{n}=68$ cows; 136 quarters).

\section{Sampling and Data Collection}

Quarter milk samples were aseptically collected by trained animal caretakers at multiple time points following inoculation during morning milking. Milk samples for scoring of clinical symptoms, bacterial growth analysis, and SCC determination were collected just before inoculation ( $\mathrm{d} 0$ ) and $1,2,3,7,14$, and $21 \mathrm{~d}$ postinoculation. The first milk squirts were used to score for clinical symptoms as described below. Next, milk samples of $10 \mathrm{~mL}$ for laboratory analyses and $30 \mathrm{~mL}$ for SCC determination and milk component measurements were taken. Milk samples for laboratory analyses were transported to the laboratory at ambient temperature, and stored at $4^{\circ} \mathrm{C}$. Within $4 \mathrm{~h}$ of sample collection, bacteriological analysis was performed as described below. Following bacteriological analysis, preinoculation milk samples were stored at $-20^{\circ} \mathrm{C}$ until antibody titer measurements were performed. Milk samples were added to vials preloaded with a preservative (sodium azide) and transported to a commercial milk quality assurance laboratory (Qlip, Zutphen, the Netherlands) for SCC determination. Preinoculation samples were also used for determination of milk composition with regard to fat percentage, total protein percentage, lactose level, and urea concentration. Determination of the SCC by flow cytometry and compositional parameters by Fourier transform infrared analyses were performed on a CombiFoss device (Foss, Hillerød, Denmark).

Before inoculation, blood was collected from the coccygeal vein using a sterile blood collection system (BD Vacutainer, Becton Dickinson B.V., Breda, the Netherlands) and, after coagulation, centrifuged for $10 \mathrm{~min}$ at $3,000 \times g$ to collect serum. Serum samples were stored at $-20^{\circ} \mathrm{C}$ until antibody titers were determined.

\section{Clinical Symptoms}

Following inoculation of bacteria, inoculated quarters were scored for local, clinical signs of mastitis once daily at the morning milking for the remainder of the experiment. Clinical scores were assigned to each quarter based on a 4 -point scale, where $0=$ no abnormalities; $1=$ slight swelling of the udder; $2=$ moderate swelling; and $3=$ severe swelling. Milk alterations were also scored using a 4-point scale, where $0=$ normal milk; 1 and $2=$ milk with a few or many clots, respectively; and 3 = serous, watery milk. Staphylococcus aureus infection was defined as the presence of $S$. aureus in milk postinoculation independent of the occurrence of clinical signs.

\section{Bacteriological Analysis of Quarter Milk}

Staphylococcus aureus in milk was determined as colony-forming units per milliliter by plating $50 \mu \mathrm{L}$ of milk onto sheep blood agar plates using the EddyJet spiral plater (LabScientific Inc., Livingston, NJ). Milk from highly infected quarters was serially diluted (10-fold) in $0.9 \%$ physiological saline before plating. After an incubation of 16 to $24 \mathrm{~h}$ at $37^{\circ} \mathrm{C}$ and $5 \% \mathrm{CO}_{2}$, numbers of colony-forming units were determined and colonyforming units per milliliter milk calculated. Bacteria were presumptively identified by colony size, morphology, and type of hemolysis, and, when required, further identified using Gram stain, and coagulase tests.

\section{Staphylococcus aureus-Specific Antibody Titers Assessed by Whole-Cell ELISA}

Antibodies directed against $S$. aureus in milk and serum were determined by ELISA. Because $S$. aureus Newbould expresses protein A that results in nonspecific binding of antibodies, the capsule-negative Reynolds strain (Albus et al., 1991) that lacks protein A was used. Staphylococcus aureus Reynolds was grown in trypticase soy broth for $20 \mathrm{~h}$ at $39.5^{\circ} \mathrm{C}$ without stirring and subsequently inactivated by overnight incubation with $0.5 \%$ formalin. Bacteria were harvested by centrifugation for 10 min at 5,000 $\times g$ and resuspended in PBS. Then, Nunc MaxiSorp plates (eBioscience, Hatfield, UK) were coated overnight at $4^{\circ} \mathrm{C}$ with $1 \mu \mathrm{g} /$ well of $S$. aureus in $0.05 M$ carbonate-bicarbonate buffer and subsequently blocked with $24 \mu \mathrm{g}$ of casein/well. Samples and positive control serum were tested in 2-fold serial dilutions and incubated for $1 \mathrm{~h}$ at $37^{\circ} \mathrm{C}$. Eight replicates of negative control serum were included. As secondary antibodies, horseradish peroxidase-conjugated sheep anti-bovine IgG monoclonal (MSD-AH, Boxmeer, the Netherlands) or $\operatorname{IgG}_{1}, \operatorname{Ig}_{2}$, and IgA (Bethyl Laboratories Inc., Montgomery, TX) were used in 1:3,000, 1:500, 1:3,000, and 1:2,000 dilutions, respectively. Tetramethylbenzidine was used as a substrate and reactions were stopped after 10 min by adding sulfuric acid. Extinctions (450 $\mathrm{nm}$ ) were measured on a Tecan Sunrise device (Tecan Group Ltd., Männedorf, Germany) using XFluor4 Software version V4.51-I4 (Tecan Group Ltd.). Antibody titers were determined using CaSpEx Software AbendVertical version 0.11 V1 (proprietary software, MSD-AH) and defined as the $\log _{2}$ dilution of the sample that would give the same absorbance as the predefined cut-off. The cut-off was defined as 2 times the average optical density of the negative controls. 


\section{Statistical Analysis}

Data management was done using Microsoft Excel (Office 2010, Microsoft Corp., Redmond, WA). The descriptive and statistical analyses were performed using the statistical software package $\mathrm{R}$ (version 2.9.1, R Foundation for Statistical Computing, Vienna, Austria). For graphical presentation of the data GraphPad Prism software (version 5; GraphPad Software Inc., La Jolla, CA) was used.

Two mixed model analyses were performed to identify factors influencing the number of $S$. aureus that were reisolated from quarter milk postinoculation. Model 1 assessed the effect of cow-related factors and the milk components fat, protein, lactose, and urea on the number of $S$. aureus. To fulfill assumptions, the numbers of $S$. aureus were $\log _{10}$-transformed. Different experimental condition such as season, feeding batch, and other conditions in the stable, were taken into account by (forced) adding experimental group as a categorical variable to the model. Time was added as fixed factor as the samples were taken at fixed time points. In the full model, farm (A or B), quarter position (front or rear), and inoculum doses were included as categorical variables. As continuous variables, DIM (per $28 \mathrm{~d}$ ), milk yield ( $\mathrm{kg} / \mathrm{d}$; per $5 \mathrm{~L})$, fat (\%), protein (\%), lactose $(\%)$, and urea $(\mathrm{mg} / \mathrm{L})$ were included.

Model 2 assessed the effect of cow-related factors and specific antibody titers on the number of $S$. aureus reisolated from quarter milk postinoculation. In this model, as in model 1, experimental group (forced) and time were included. As continuous variables, DIM (per $28 \mathrm{~d}$ ), milk yield ( $\mathrm{kg} / \mathrm{d}$; per $5 \mathrm{~L})$, milk $\operatorname{IgG}_{1}$, milk $\operatorname{IgG}_{2}$, milk IgA, and serum IgG concentrations were included. Quarter position was excluded from this model because it was the same for all quarters analyzed in this model. Farm and inoculum dose were excluded because they were incorporated in the variable experimental group.

For both models, residuals were assessed for normal distribution and constant variance. Cow was added to the models as random effect to take repeated measurements within a cow into account, as well as a random slope for time within a cow. For the linear mixed effect models, the R package nlme was used. Function dredge ( $\mathrm{R}$ package MuMIn) was used to find the best model between al competing models based on the Akaike's information criterion.

To confirm the significant associations observed in the mixed model analyses, differences in the milk fat percentage and the $\operatorname{IgG}_{1}$ titer in milk between quarters with different $S$. aureus shedding patterns were calculated using the 2 -tailed $t$-test. $P$-values $<0.05$ were considered significant.

\section{RESULTS}

\section{Intramammary Infection}

Following intramammary inoculation, 135 of 136 quarters became infected with $S$. aureus, as measured by the detection of $S$. aureus in quarter milk $1 \mathrm{~d}$ postinoculation. Staphylococcus aureus was undetectable in milk from 1 quarter throughout the entire experimental period of 3 wk. The number of $S$. aureus reisolated from milk of 67 of 136 quarters (of 48 cows) was below the detection limit of $20 \mathrm{cfu} / \mathrm{mL}$ on at least one sampling occasion postinoculation (d 1, 2, 3, 7, 14, or 21). Most of these quarters were positive again at one of the other consecutive samplings. The numbers of $S$. aureus reisolated from milk of 20 of 67 quarters (of 18 cows) were below the detection limit on at least 2 consecutive sampling occasions and remained negative until the end of the experimental period. Overall, the shedding dynamics of $S$. aureus could be divided into 2 patterns: quarters with a decreasing number of $S$. aureus $(\mathrm{n}=60)$ and quarters with a constant or increasing number of $S$. aureus $(\mathrm{n}=76$; Figure 1$)$. The SCC pattern postinoculation was similar among all cows, regardless of the $S$. aureus shedding pattern observed (Figure 2). The mean $\log _{10}$ SCC (cells per $\mathrm{mL} / 1,000$ ) of quarters used in model 1 was $1.06 \pm 0.29$ cells $/ \mathrm{mL}$, and the mean SCC of quarters used in model 2 was $1.02 \pm 0.35$ cells/ $\mathrm{mL}$ before inoculation. Experimental inoculation of $S$. aureus resulted in subclinical mastitis, as reflected by generally low milk and udder scores and only a slight decrease in the mean daily milk yield during the first 4 d postinoculation (Figure 3 ).

\section{Factors Influencing the Numbers of S. aureus Reisolated from Quarter Milk Postinoculation}

A total of 68 cows ( $n=136$ quarters) received intramammary inoculation of $S$. aureus. For model 1, which aimed to identify associations between milk components and the number of $S$. aureus reisolated from milk postinoculation, data of 52 challenged quarters were excluded because the amount of the milk sample was insufficient to perform all tests accurately, resulting in one or more missing values per milk sample. In total, 136 quarter milk samples were analyzed for fat percentage, total protein percentage, lactose level, and urea concentration. Overall, 84 of 544 milk parameter concentrations $(15 \%)$ could not be obtained. In the statistical analyses used, all data of a quarter were excluded when a single value was missing. Quarters with missing values were equally divided over the groups with a decreasing and constant or increasing 
shedding pattern (18 of 60 and 20 of 76 , respectively). Because data on the immunoglobulin levels of the quarters with missing milk composition concentrations were available, quarters were not excluded from the entire study but included in model 2 , which aimed to identify associations between specific antibody levels at the time of inoculation and the number of $S$. aureus reisolated from milk postinoculation. An overview of the parameter characteristics used in model 1 is given in Table 1 (mean $\pm \mathrm{SD}$ ). An overview of the parameter characteristics used in model 2 is given in Table 2 (mean $\pm \mathrm{SD}$ ). Data of $S$. aureus-specific antibody titers were available for 63 quarters of 32 cows.

In model 1 , the variables quarter position, inoculation dose, DIM, milk yield, protein, and lactose were removed from the full model because they did not improve the fit significantly. The final model, including time, experimental group (forced), farm, fat percentage, and urea concentration, identified a positive association between the milk fat percentage and the number of $S$. aureus reisolated from quarter milk. Results indicate that an increase in the fat percentage of 1 resulted in a 2.5-fold increase in the numbers of $S$. aureus $(P=$ 0.03). A direct comparison of the milk fat percentage between quarters with a decreasing and pattern and a constant or increasing $S$. aureus shedding pattern showed no significant differences $(P=0.09$; Figure $4 \mathrm{~A})$.

In model 2, the variables DIM, milk yield, milk $\operatorname{IgG}_{2}$, milk $\operatorname{IgA}$, and serum $\operatorname{IgG}$ were removed from the full model because they did not improve the fit significantly. The final model, including time, experimental group (forced), and milk $\operatorname{IgG}_{1}$ antibody titers, identified a negative association between the $S$. aureusspecific $\operatorname{IgG}_{1}$ titer in quarter milk and the numbers of $S$. aureus. An increase in $\operatorname{IgG}_{1}$ titer of $1 \log _{2}$ was associated with a 0.7 -fold reduction in the numbers of $S$. aureus $(P=0.04)$. A direct comparison of specific $\operatorname{IgG}_{1}$ titers between quarters with different $S$. aureus shedding patterns showed a significantly higher $\operatorname{IgG}_{1}$ titer in quarters with a decreasing shedding pattern compared
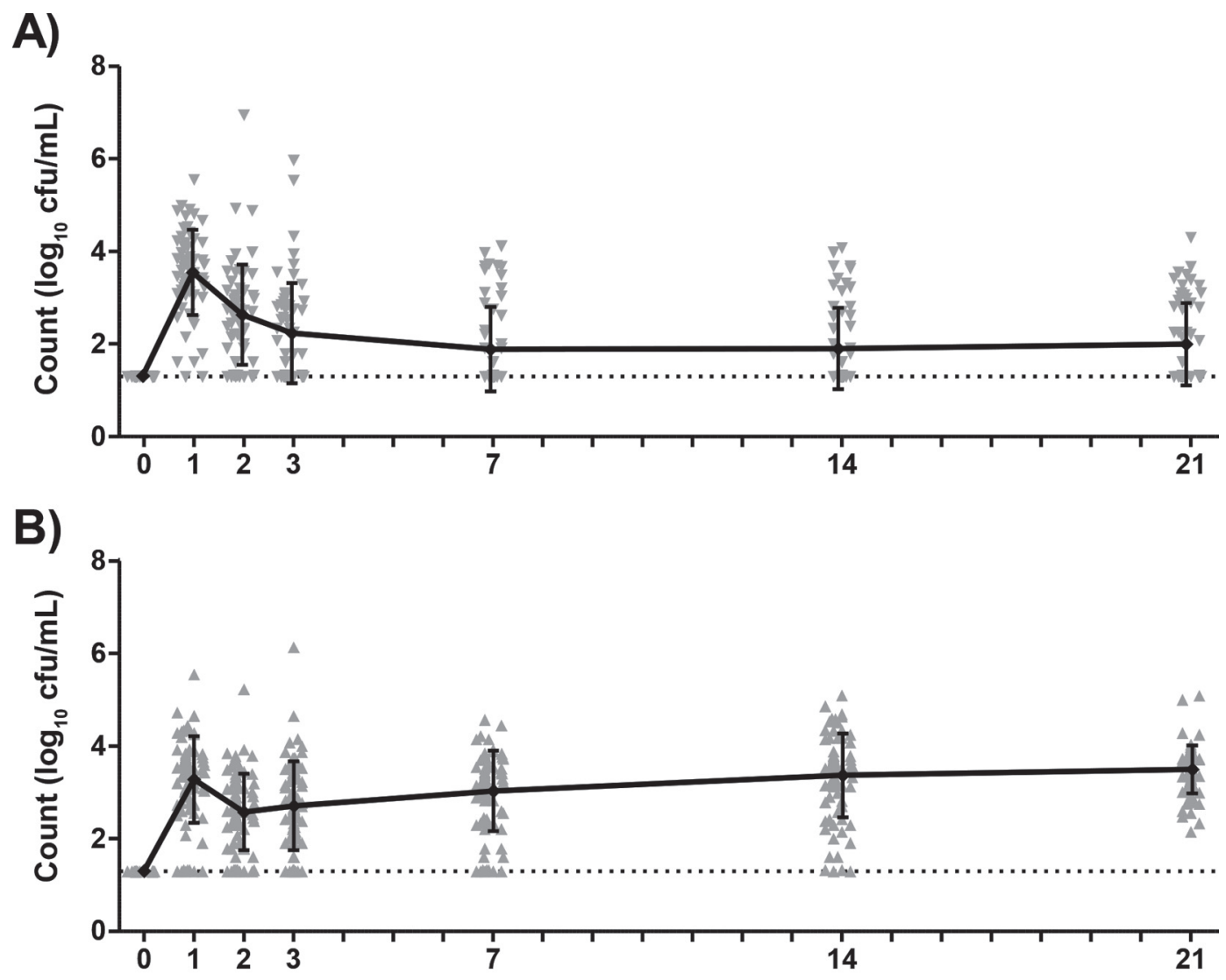

Days relative to inoculation

Figure 1. Staphylococcus aureus shedding patterns postinoculation. Two milked-out quarters per cow were experimentally inoculated with $S$. aureus and bacterial shedding (expressed as $\log _{10} \mathrm{cfu} / \mathrm{mL}$ ) was measured over a 21-d period. The graph represents 2 different shedding patterns: (A) quarters with decreasing numbers of $S$. aureus $(\mathrm{n}=60)$, and $(\mathrm{B})$ quarters with constant or increasing numbers of $S$. aureus $(\mathrm{n}=76)$. Lines represent the mean $\pm \mathrm{SD}$. The detection limit is $20 \mathrm{cfu} / \mathrm{mL}\left(1.3 \log _{10} \mathrm{cfu} / \mathrm{mL}\right.$; dotted line $)$. 

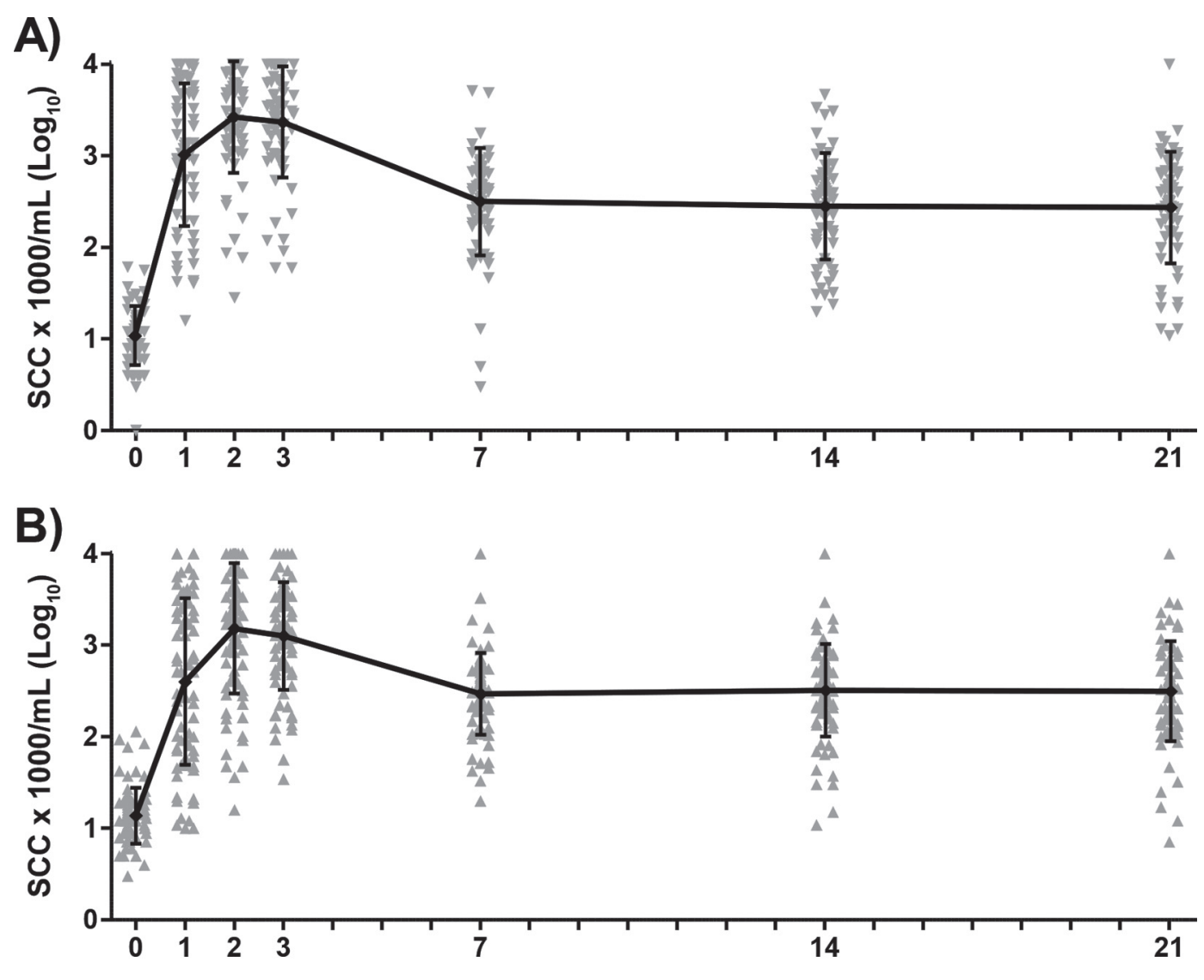

Days relative to inoculation

Figure 2. Quarter milk SCC postinoculation. Following experimental inoculation of Staphylococcus aureus, the SCC was determined. The graph represents SCC (mean $\pm \mathrm{SD}$ ) in cows with different $S$. aureus shedding patterns: $(\mathrm{A})$ quarters with decreasing numbers of $S$. aureus $(\mathrm{n}=$ $60)$, and (B) quarters with constant or increasing numbers of $S$. aureus $(\mathrm{n}=76)$. The detection $\operatorname{limit}$ is $4 \log _{10}$.

with quarters with a constant or increasing shedding pattern $(P=0.002$; Figure 4B).

We observed a significant difference in the $S$. aureusspecific serum IgG titer between cows housed at the 2 experimental farms $(P<0.00)$. The mean $\log _{2}$ serum IgG titers of cows housed at farm A was 13.6, whereas the mean $\log _{2}$ serum titers of cows housed at farm B was 16.7. This difference was not reflected in milk $\operatorname{IgG}_{1}$ or $\mathrm{IgG}_{2}$ titers (Supplementary Figure S1; http://dx.doi. org/10.3168/jds.2015-10648).

No association between the quarter position and the numbers of $S$. aureus reisolated from quarter milk was observed. A total of 115 front quarters and 21 rear quarters were inoculated in this study. The 2 different shedding patterns (Figure 1) were represented in both front and rear quarters with almost equal distribution. Rear quarters represented decreasing numbers of $S$. aureus $(7 / 60 ; 11.6 \%)$ and quarters with constant or increasing number of $S$. aureus $(14 / 76 ; 18.4 \%)$ postinoculation.
To analyze whether the association between the milk fat concentration and the $S$. aureus-specific $\operatorname{IgG}_{1}$ titer in milk and the numbers of $S$. aureus reisolated from milk was cow or quarter related, the correlation between these 2 factors and the 2 inoculated quarters of the same cow were analyzed. Both the milk fat percentage $\left(\mathrm{R}^{2}=0.794\right)$ and $S$. aureus-specific $\operatorname{IgG}_{1}$ titers $\left(\mathrm{R}^{2}=\right.$ $0.867)$ at the time of inoculation were comparable between the 2 quarters of the same cow (Supplementary Figure S2; http://dx.doi.org/10.3168/jds.2015-10648).

\section{DISCUSSION}

This study aimed to evaluate the association between milk composition parameters and the shedding dynamics of $S$. aureus following experimental intramammary inoculation. The enrollment criteria in this study in combination with the experimental infection provided a unique study population of cows with similar man- 
Table 1. Overview of cow and milk characteristics of animals (means with SD in parentheses) enrolled in model 1

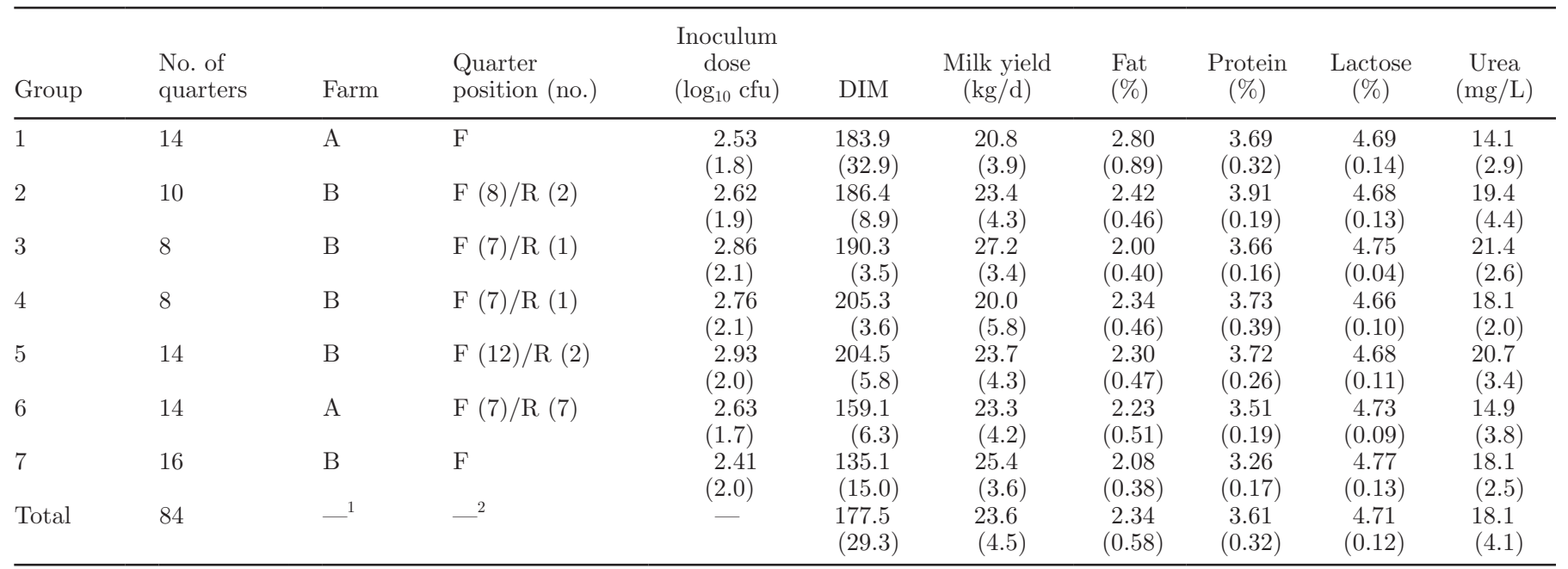

${ }^{1} \mathrm{~A}=28 / 84 ; \mathrm{B}=56 / 84$.

${ }^{2} \mathrm{~F}$ (front) $=71 / 84 ; \mathrm{R}$ (rear) $=13 / 84$.

agement and herd characteristics, enabling analysis of individual cow- and quarter-related factors, including the milk components fat, protein, lactose, urea, and S. aureus-specific antibody titers, with the severity of experimentally induced $S$. aureus bovine mastitis.

In the studies presented here, experimental inoculations with $S$. aureus resulted in subclinical mastitis with $>99 \%$ infected quarters postinoculation. Both a decreasing shedding pattern and a constant or increas- ing $S$. aureus pattern were observed during the experimental period. Statistical models revealed a significant positive and negative contribution to the numbers of $S$. aureus reisolated from quarter milk postinoculation for milk fat percentage and $S$. aureus-specific $\operatorname{IgG}_{1}$ titer in milk, respectively. In agreement with these results, quarters with a decreasing $S$. aureus shedding pattern showed a significantly higher $\operatorname{IgG}_{1}$ titer preinoculation compared with quarters with a constant or increasing

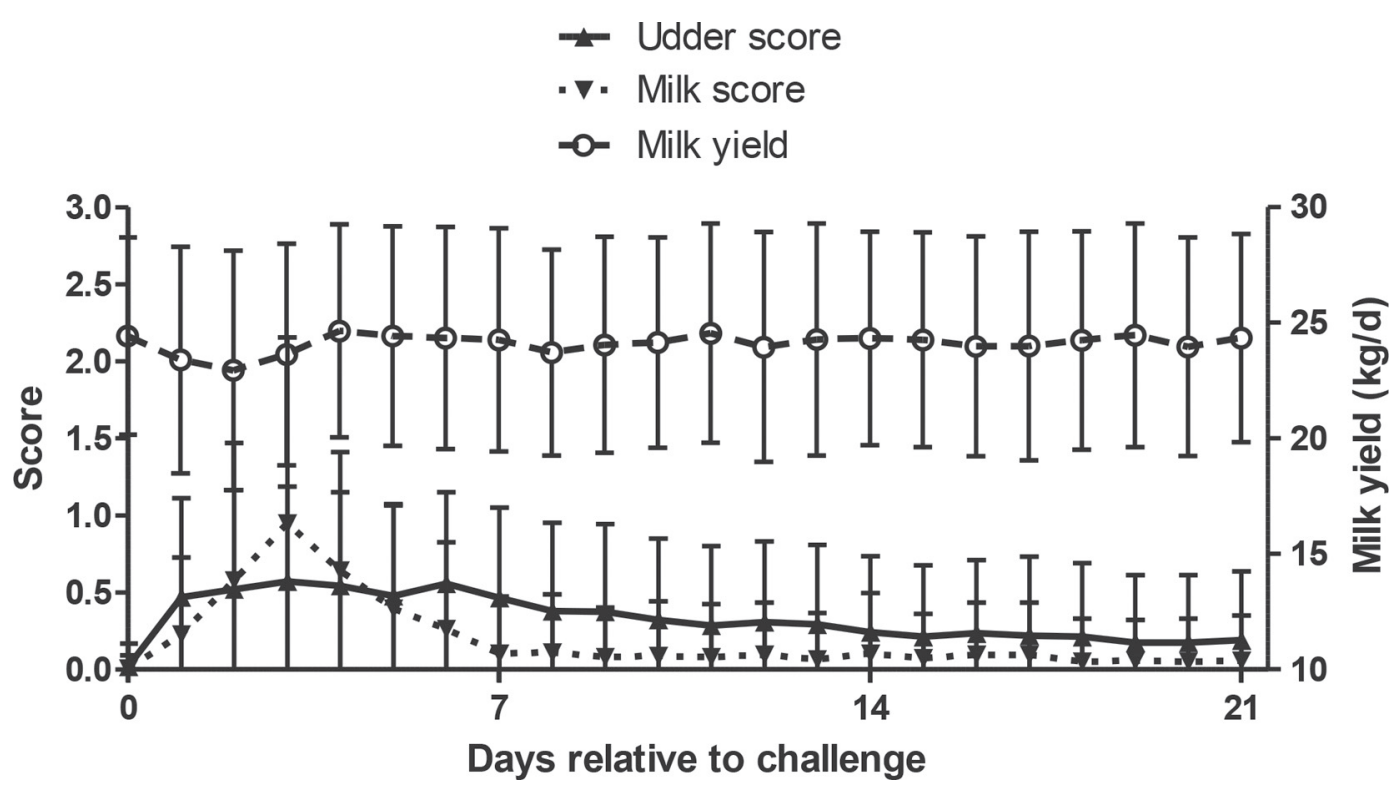

Figure 3. Udder and milk scores and daily milk yield postinoculation. Following experimental inoculation of Staphylococcus aureus, a scoring system was used to monitor (sub)clinical mastitis. A score of 0 indicates a lack of clinical signs of mastitis; the maximum udder score of 3 indicates severe udder swelling, and the maximum milk score of 3 indicates serous, watery milk. Results are expressed as mean \pm SD. The graph represents data from 136 challenged quarters. 
A)

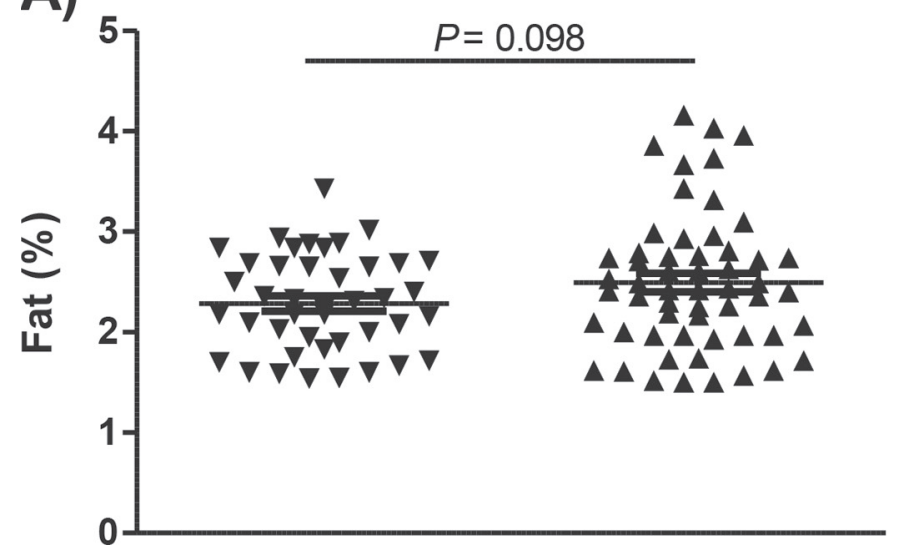

B)

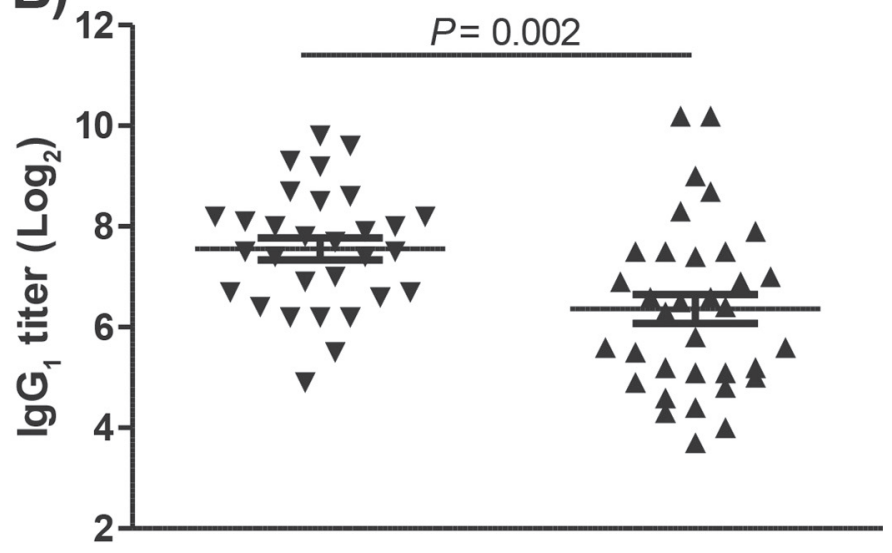

Figure 4. Differences in milk fat percentage and Staphylococcus aureus-specific $\operatorname{IgG}_{1}$ titers between quarters with different shedding patterns. Differences in the milk fat percentages $(\mathrm{A})$ and $S$. aureus-specific $\operatorname{IgG}_{1}$ titers (B) before inoculation between quarters showing a decreasing ( $\mathbf{}$ ) and a constant or increasing $(\wedge)$ S. aureus shedding pattern postinoculation are depicted (mean \pm SEM).

S. aureus shedding pattern. In contrast, no differences in the milk fat percentages were observed between quarters with different $S$. aureus shedding patterns.

A key component of the bovine innate intramammary immune response against $S$. aureus is the ability of immune cells, which are resident in the milk, to phagocytose $S$. aureus. For phagocytosis to occur, recognition between bacteria and phagocytes is conferred by immunoglobulins and complement components. In the normal healthy mammary gland, macrophages constitute the predominant cell type (Paape et al., 2002). Phagocytosis by macrophages can be enhanced by $\operatorname{IgG}_{1}$ antibodies, which is the main antibody isotype in normal bovine milk (Guidry et al., 1980; Howard et al., 1980); $\operatorname{IgG}_{1}$ also plays a role in complement activation (McGuire et al., 1979). However, in the healthy bovine mammary gland, the alternative, antibody-independent complement pathway has been shown to be the sole operating complement pathway (Rainard and Poutrel, 1995, 2000; Barrio et al., 2003). The classical complement pathway, which does require the presence of antibodies because $\mathrm{C} 1 \mathrm{q}$ activation is obtained by antigen:antibody complex recognition, was shown to be inactive due to limited concentrations of C1q (Rainard and Poutrel, 1995). This suggests that the negative relationship between the $S$. aureus-specific $\mathrm{IgG}_{1}$ titer in milk at the time of inoculation and the numbers of $S$. aureus reisolated from quarter milk postinoculation observed in this study is likely due to an increased phagocytic capacity of macrophages rather than increased complement activation.

Staphylococcus aureus prevents opsonophagocytosis by expressing capsule polysaccharides. Capsule polysaccharide serotype-specific antibodies are required to increase phagocytosis (Kampen et al., 2005). Thus, for opsonophagocytosis of the $S$. aureus Newbould 305 CP5 (capsule-positive) strain used for experimental inoculations, CP5-specific antibodies are required. In the present study, $\operatorname{IgG}_{1}$ antibody titers were determined using the capsule-negative $S$. aureus Reynolds strain to prevent nonspecific binding of antibodies and protein A in the ELISA. Because CP5-specific antibody levels

Table 2. Overview of cow and milk characteristics of animals enrolled in model 2

\begin{tabular}{|c|c|c|c|c|c|c|c|}
\hline Group & $\begin{array}{l}\text { No. of } \\
\text { quarters }\end{array}$ & $\operatorname{DIM}^{1}$ & $\begin{array}{l}\text { Milk yield }^{1} \\
\quad(\mathrm{~kg} / \mathrm{d})\end{array}$ & $\begin{array}{c}\text { Milk }^{2} \\
\left(\operatorname{IgG}_{1}\right)\end{array}$ & $\begin{array}{l}\text { Milk }^{2} \\
\left(\operatorname{IgG}_{2}\right)\end{array}$ & $\begin{array}{l}\text { Milk }^{2} \\
(\operatorname{IgA} A)\end{array}$ & $\begin{array}{c}\text { Serum }^{2} \\
(\operatorname{Ig} G)\end{array}$ \\
\hline 1 & 14 & $\begin{array}{l}183.9 \\
(32.9)\end{array}$ & $\begin{array}{c}20.8 \\
(3.9)\end{array}$ & $\begin{array}{c}6.5 \\
(1.8)\end{array}$ & $\begin{array}{c}3.1 \\
(0.7)\end{array}$ & $\begin{array}{c}5.6 \\
(0.4)\end{array}$ & $\begin{array}{l}13.1 \\
(1.1)\end{array}$ \\
\hline 6 & 18 & $\begin{array}{r}159.4 \\
(6.2)\end{array}$ & $\begin{array}{l}22.4 \\
(4.5)\end{array}$ & $\begin{array}{c}6.7 \\
(1.7)\end{array}$ & $\begin{array}{c}3.7 \\
(1.1)\end{array}$ & $\begin{array}{c}6.6 \\
(0.9)\end{array}$ & $\begin{array}{l}14.1 \\
(1.1)\end{array}$ \\
\hline 7 & 31 & $\begin{array}{l}138.1 \\
(15.8)\end{array}$ & $\begin{array}{c}25.5 \\
(3.4)\end{array}$ & $\begin{array}{c}7.3 \\
(1.4)\end{array}$ & $\begin{array}{c}4.0 \\
(1.0)\end{array}$ & $\begin{array}{c}5.2 \\
(1.0)\end{array}$ & $\begin{array}{l}16.7 \\
(0.7)\end{array}$ \\
\hline Total & 63 & $\begin{array}{l}154.5 \\
(26.0)\end{array}$ & $\begin{array}{l}23.6 \\
(4.3)\end{array}$ & $\begin{array}{c}6.9 \\
(1.6)\end{array}$ & $\begin{array}{c}3.7 \\
(1.0)\end{array}$ & $\begin{array}{c}5.7 \\
(1.1)\end{array}$ & $\begin{array}{l}15.2 \\
(1.8)\end{array}$ \\
\hline
\end{tabular}

${ }^{1}$ Mean (SD).

${ }^{2}$ Mean (SD) Staphylococcus aureus Reynolds bacterin specific antibody titer $\left(\log _{2}\right)$. 
were not determined in the current study, the actual effect of $\operatorname{IgG}_{1}$ on phagocytosis might have been underestimated.

Although it is known that $\operatorname{IgG}_{2}$ antibodies also enhance the activity of phagocytic cells, an association between $\operatorname{IgG}_{2}$ antibodies and the numbers of $S$. aureus in milk could not be identified in this study. This is in line with previous results indicating that receptors for bovine $\operatorname{Ig} \mathrm{G}_{2}$ were either absent from or present at a low level on the surface of macrophages but abundantly expressed on PMN (Howard et al., 1980). Both $\mathrm{IgG}_{2}$ levels and the number of PMN are relatively low in normal milk but rapidly increase following recruitment after infiltration of the mammary gland (Leitner et al., 2000; Paape et al., 2002; Hurley and Theil, 2011). The cows used for this study were selected based on the absence of intramammary infections, resulting in relatively low $\operatorname{IgG}_{2}$ levels and PMN concentrations in their milk at the time of inoculation, which might explain the lack of association between $\operatorname{IgG}_{2}$ levels and the numbers of $S$. aureus. Postinoculation, the recruitment of PMN (among other cell types) is reflected by increased quarter milk SCC. Therefore, $\operatorname{IgG}_{2}$ might play a role in the host's defense against $S$. aureus during later stages of infection.

In this study, we observed a significant difference in preexisting $S$. aureus-specific serum IgG titers between cows housed at the 2 experimental farms. Because cows were not immunized against $S$. aureus before enrollment, specific antibody titers are thought to be a result of natural exposure to the pathogen at various body sites such as the teat skin and external orifices (Roberson et al., 1994). The differences in serum antibody titers between cows on the different farms were not reflected in the milk antibody titers. This might indicate that enhancing systemic antibodies might not lead directly to an increase in local immunoglobulin levels in the milk. Therefore, immunization techniques that specifically improve antibody levels in milk should be considered (Boerhout et al., 2015).

Whereas the phagocytic capacity of macrophages and neutrophils is enhanced by $\operatorname{IgG}_{1}$ antibodies, phagocytosis can be inhibited by the presence of milk fat globules. When encountering fat globules within the mammary gland, phagocytes start to ingest these globules. As a result, the ability of the cell to lower the $\mathrm{pH}$ of phagosomes is impaired, affecting digestion by lysosomal enzymes and thereby reducing the phagocytic capacity of the phagocyte (Reinitz et al., 1982). Reduced phagocytosis and subsequent killing of $S$. aureus might explain the positive association observed in this study between milk fat percentage preinoculation and the numbers of $S$. aureus reisolated from quarter milk postinoculation. The effect of fat on phagocytosis has previously been observed in a murine model, where chemotaxis of neutrophils was decreased after a high fat diet was provided, resulting in impaired phagocytosis of S. aureus (Svahn et al., 2015). High concentrations of fat in milk preinoculation may benefit $S$. aureus in more than one way because $S$. aureus is able to form a biofilm type of growth by binding to milk fat globules (Ali-Vehmas et al., 1997). Biofilm formation is thought to play an important role in the pathogenesis of $S$. aureus infections because it contributes to the evasion of the cows' immunological defense mechanism (Fox et al., 2005; Lee et al., 2014).

On many farms, milk fat percentages are measured routinely at the bulk tank level but also on an individual cow basis. The fat percentages measured during these routine analyses might not be directly comparable to the fat percentages measured in this study because of differences in sampling methods. To associate milk fat percentages with susceptibility to intramammary $S$. aureus growth, it is important to avoid variation and to standardize the sampling time and method because milk fat concentrations are highly variable and influenced by season, nutrition, genetic variation, and even the time of milking (Stoop et al., 2008; Forsbäck et al., 2010; Duchemin et al., 2013). Therefore, using milk fat percentage as an indicator for health disturbances is challenging. In addition, although the milk fat percentage preinoculation was associated with the numbers of $S$. aureus reisolated postinoculation, there was no association with the observed shedding patterns. This suggests that milk fat percentage is influenced during the course of the infection. Future research focusing on the dynamics of milk fat percentage over the course of infection is required to conclude whether fat percentage is indeed subject to changes by intramammary growth of $S$. aureus.

It has been suggested that the position of a quarter on the mammary gland affects its susceptibility to naturally acquired $S$. aureus infections (Barkema et al., 1997; Reyher et al., 2013; Yang et al., 2015). Results of this study show no association between front or rear quarters and the numbers of $S$. aureus reisolated from quarter milk. The position of the quarter is bypassed under the experimental inoculation conditions applied in this study, suggesting that, once the organism is inside, the position of the quarter is insignificant to $S$. aureus. This is in line with the observation that, at least when sampled at the same time via the same procedure, both milk fat percentage and $\operatorname{IgG}_{1}$ titers are comparable between quarters of the same cow regardless of their positions. Thus, quarter position and the physiological condition of the teat are likely to play a 
role in susceptibility to bacterial entrance, rather than in the establishment of an infection once the bacteria has penetrated the mammary gland. This underlines the importance of udder health management and improved milking routines in the prevention of mastitis (Neijenhuis et al., 2001; Dingwell et al., 2004).

The fact that milk fat concentrations and $\mathrm{IgG}_{1}$ titers in milk are similar between the 2 quarters of the same mammary gland and interquarter differences in bacterial shedding dynamics are frequently observed, it is unlikely that susceptibility to $S$. aureus-induced mastitis is solely dependent on these 2 milk components. Therefore, the possible influence of milk factors that were not analyzed in this study, such as cytokines, complement components, and lactoperoxidase (Stelwagen et al., 2009), the milk microbiome (Fernández et al., 2013), and extracellular, cell-derived vesicles (Zonneveld et al., 2014; Lai et al., 2015), on the bacterial growth of $S$. aureus in milk needs to be elucidated in future studies. Besides focusing on specific preselected compounds, nontargeted proteomics approaches may also be considered (Hettinga et al., 2015).

\section{CONCLUSIONS}

The aim of this study was to identify whether routinely measured milk components and $S$. aureus-specific antibody titers influence the numbers of $S$. aureus that can be reisolated from quarter milk following experimental inoculation. Our results revealed a significant positive association of the milk fat percentage preinoculation and the numbers of $S$. aureus reisolated from milk postinoculation. In addition, results showed that the $S$. aureus-specific IgG1 titer preinoculation is negatively associated with the numbers of $S$. aureus reisolated from milk postinoculation. These findings support the ongoing effort to develop a vaccine against bovine $S$. aureus-induced mastitis and indicate that stimulation of the humoral immune response in milk against this bacterium might contribute to protection.

\section{ACKNOWLEDGMENTS}

The authors thank Marca Wauben (Department of Biochemistry and Cell Biology, Utrecht University, the Netherlands) for useful discussions and critically reading the manuscript. The authors thank our farmers, MSD-AH animal caretakers, and the MSD-AH veterinarian for excellent care and handling of the cows. This study was financed by the Alternatives for Antibiotics (ALTANT) project subsidized by the Ministry of Economic Affairs, Agriculture and Innovation of the Dutch government.

\section{REFERENCES}

Albus, A., R. D. Arbeit, and J. C. Lee. 1991. Virulence of Staphylococcus aureus mutants altered in type 5 capsule production. Infect. Immun. 59:1008-1014.

Ali-Vehmas, T., P. Westphalen, V. Myllys, and M. Sandholm. 1997. Binding of Staphylococcus aureus to milk fat globules increases resistance to penicillin-G. J. Dairy Res. 64:253-260.

Bannerman, D. D., M. J. Paape, J. W. Lee, X. Zhao, J. C. Hope, and P. Rainard. 2004. Escherichia coli and Staphylococcus aureus elicit differential innate immune responses following intramammary infection. Clin. Diagn. Lab. Immunol. 11:463-472.

Barkema, H. W., Y. H. Schukken, T. J. G. M. Lam, D. T. Galligan, M. L. Beiboer, and A. Brand. 1997. Estimation of interdependence among quarters of the bovine udder with subclinical mastitis and implications for analysis. J. Dairy Sci. 80:1592-1599.

Barrio, M. B., P. Rainard, and B. Poutrel. 2003. Milk complement and the opsonophagocytosis and killing of Staphylococcus aureus mastitis isolates by bovine neutrophils. Microb. Pathog. 34:1-9.

Boerhout, E. M., M. Vrieling, L. Benedictus, A. J. J. M. Daemen, L. Ravesloot, V. P. M. G. Rutten, P. J. M. Nuijten, J. A. G. van Strijp, A. P. Koets, and S. W. F. Eisenberg. 2015. Immunization routes in cattle impact the levels and neutralizing capacity of antibodies induced against $S$. aureus immune evasion proteins. Vet. Res. 46:115.

Bouchard, D., V. Peton, S. Almeida, C. Le Maréchal, A. Miyoshi, V. Azevedo, N. Berkova, L. Rault, P. François, J. Schrenzel, S. Even, D. Hernandez, and Y. Le Loir. 2012. Genome sequence of Staphylococcus aureus Newbould 305, a strain associated with mild bovine mastitis. J. Bacteriol. 194:6292-6293.

Camussone, C. M., N. Pujato, M. S. Renna, C. M. Veaute, B. Morein, I. S. Marcipar, and L. F. Calvinho. 2014. Immune response and functional role of antibodies raised in heifers against a Staphylococcus aureus CP5 lysate and recombinant antigens vaccine formulated with Iscom Matrix adjuvant. Vet. Immunol. Immunopathol. 162:96-107.

Cui, J. C., B. J. Zhang, Y. C. Lin, Q. K. Wang, A. D. Qian, A. Nakane, D. L. Hu, and G. Z. Tong. 2010. Protective effect of glutathione S-transferase-fused mutant staphylococcal enterotoxin C against Staphylococcus aureus-induced bovine mastitis. Vet. Immunol. Immunopathol. 135:64-70.

CVB. 2012. CVB Tabellenboek Veevoeding. Dutch Feeding Tables. 9th ed. CVB, Den Haag, the Netherlands.

Dingwell, R. T., K. E. Leslie, Y. H. Schukken, J. M. Sargeant, L. L. Timms, T. F. Duffield, G. P. Keefe, D. F. Kelton, K. D. Lissemore, and J. Conklin. 2004. Association of cow and quarter-level factors at drying-off with new intramammary infections during the dry period. Prev. Vet. Med. 63:75-89.

Duchemin, S., H. Bovenhuis, W. M. Stoop, A. C. Bouwman, J. A. van Arendonk, and M. H. Visker. 2013. Genetic correlation between composition of bovine milk fat in winter and summer, and DGAT1 and SCD1 by season interactions. J. Dairy Sci. 96:592-604.

Fernández, L., S. Langa, V. Marin, A. Maldonado, E. Jimenez, R. Martin, and J. Rodriguez. 2013. The human milk microbiota: Origin and potential roles in health and disease. Pharmacol. Res. 69:1-10.

Forsbäck, L., H. Lindmark-Månsson, A. Andrén, M. Akerstedt, L. Andrée, and K. Svennersten-Sjaunja. 2010. Day-to-day variation in milk yield and milk composition at the udder-quarter level. J. Dairy Sci. 93:3569-3577.

Fox, L. K., R. N. Zadoks, and C. T. Gaskins. 2005. Biofilm production by Staphylococcus aureus associated with intramammary infection. Vet. Microbiol. 107:295-299.

Guidry, A. J., R. E. Pearson, M. J. Paape, and W. F. Williams. 1980. Relationship among leukocyte phagocytosis, milk immunoglobulins, and susceptibility to intramammary infection. Am. J. Vet. Res. 41:997-1001.

Hettinga, K. A., F. M. Reina, S. Boeren, L. Zhang, G. H. Koppelman, D. S. Postma, J. J. Vervoort, and A. H. Wijga. 2015. Difference in the breast milk proteome between allergic and non-allergic mothers. PLoS ONE 10:e0122234. 
Howard, C. J., G. Taylor, and J. Brownlie. 1980. Surface receptors for immunoglobulin on bovine polymorphonuclear neutrophils and macrophages. Res. Vet. Sci. 29:128-130.

Hurley, W. L., and P. K. Theil. 2011. Perspectives on immunoglobulins in colostrum and milk. Nutrients 3:442-474.

Kampen, A. H., T. Tollersrud, and A. Lund. 2005. Staphylococcus aureus capsular polysaccharide types 5 and 8 reduce killing by bovine neutrophils in vitro. Infect. Immun. 73:1578-1583.

Krömker, V., F. Pfannenschmidt, K. Helmke, R. Andersson, and N. T. Grabowski. 2012. Risk factors for intramammary infections and subclinical mastitis in post-partum dairy heifers. J. Dairy Res. 79:304-309.

Lai, F. W., B. D. Lichty, and D. M. Bowdish. 2015. Microvesicles: Ubiquitous contributors to infection and immunity. J. Leukoc. Biol. 97:237-245.

Lee, S. H., B. L. Mangolin, J. L. Gonçalves, D. V. Neeff, M. P. Silva, A. G. Cruz, and C. A. Oliveira. 2014. Biofilm-producing ability of Staphylococcus aureus isolates from Brazilian dairy farms. J. Dairy Sci. 97:1812-1816.

Leelahapongsathon, K., Y. H. Schukken, and W. Suriyasathaporn. 2014. Quarter, cow, and farm risk factors for intramammary infections with major pathogens relative to minor pathogens in Thai dairy cows. Trop. Anim. Health Prod. 46:1067-1078.

Leitner, G., O. Krifucks, M. D. Kiran, and N. Balaban. 2011. Vaccine development for the prevention of staphylococcal mastitis in dairy cows. Vet. Immunol. Immunopathol. 142:25-35.

Leitner, G., B. Yadlin, A. Glickman, M. Chaffer, and A. Saran. 2000. Systemic and local immune response of cows to intramammary infection with Staphylococcus aureus. Res. Vet. Sci. 69:181-184.

McGuire, T. C., A. J. Musoke, and T. Kurtti. 1979. Functional properties of bovine IgG1 and IgG2: interaction with complement, macrophages, neutrophils and skin. Immunology 38:249-256.

Middleton, J. R., J. Ma, C. L. Rinehart, V. N. Taylor, C. D. Luby, and B. J. Steevens. 2006. Efficacy of different Lysigin formulations in the prevention of Staphylococcus aureus intramammary infection in dairy heifers. J. Dairy Res. 73:10-19.

Neijenhuis, F., H. W. Barkema, H. Hogeveen, and J. P. Noordhuizen. 2001. Relationship between teat-end callosity and occurrence of clinical mastitis. J. Dairy Sci. 84:2664-2672.

Nordhaug, M. L., L. L. Nesse, N. L. Norcross, and R. Gudding. 1994. A field trial with an experimental vaccine against Staphylococcus aureus mastitis in cattle. 2. Antibody response. J. Dairy Sci. $77: 1276-1284$.

Paape, M., J. Mehrzad, X. Zhao, J. Detilleux, and C. Burvenich. 2002. Defense of the bovine mammary gland by polymorphonuclear neutrophil leukocytes. J. Mammary Gland Biol. Neoplasia 7:109-121.

Park, Y. K., H. C. Koo, S. H. Kim, S. Y. Hwang, W. K. Jung, J. M. Kim, S. Shin, R. T. Kim, and Y. H. Park. 2007. The analysis of milk components and pathogenic bacteria isolated from bovine raw milk in Korea. J. Dairy Sci. 90:5405-5414.

Pellegrino, M., J. Giraudo, C. Raspanti, L. Odierno, and C. Bogni. 2010. Efficacy of immunization against bovine mastitis using a Staphylococcus aureus avirulent mutant vaccine. Vaccine 28:45234528.

Peton, V., D. S. Bouchard, S. Almeida, L. Rault, H. Falentin, J. Jardin, G. Jan, D. Hernandez, P. François, J. Schrenzel, V. Azevedo, A. Miyoshi, N. Berkova, S. Even, and Y. Le Loir. 2014. Fine-tuned characterization of Staphylococcus aureus Newbould 305, a strain associated with mild and chronic mastitis in bovines. Vet. Res. 45:106.

Pilla, R., M. Malvisi, G. G. Snel, D. Schwarz, S. König, C. P. Czerny, and R. Piccinini. 2013. Differential cell count as an alternative method to diagnose dairy cow mastitis. J. Dairy Sci. 96:1653-1660.

Pilla, R., D. Schwarz, S. König, and R. Piccinini. 2012. Microscopic differential cell counting to identify inflammatory reactions in dairy cow quarter milk samples. J. Dairy Sci. 95:4410-4420.
Rainard, P., and B. Poutrel. 1995. Deposition of complement components on Streptococcus agalactiae in bovine milk in the absence of inflammation. Infect. Immun. 63:3422-3427.

Rainard, P., and B. Poutrel. 2000. Generation of complement fragment C5a in milk is variable among cows. J. Dairy Sci. 83:945-951.

Reinitz, D. M., M. J. Paape, and I. H. Mather. 1982. Effect of phagocytosed fat and casein on the intraphagosomal $\mathrm{pH}$ in bovine polymorphonuclear leukocytes. Proc. Soc. Exp. Biol. Med. 170:281285

Reyher, K. K., I. R. Dohoo, and C. A. Muckle. 2013. Evaluation of clustering of new intramammary infections in the bovine udder, including the impact of previous infections, herd prevalence, and somatic cell count on their development. J. Dairy Sci. 96:219-233.

Roberson, J. R., L. K. Fox, D. D. Hancock, J. M. Gay, and T. E. Besser. 1994. Ecology of Staphylococcus aureus isolated from various sites on dairy farms. J. Dairy Sci. 77:3354-3364.

Schukken, Y. H., K. E. Leslie, D. A. Barnum, B. A. Mallard, J. H. Lumsden, P. C. Dick, G. H. Vessie, and M. E. Kehrli. 1999. Experimental Staphylococcus aureus intramammary challenge in late lactation dairy cows: quarter and cow effects determining the probability of infection. J. Dairy Sci. 82:2393-2401.

Shkreta, L., B. G. Talbot, M. S. Diarra, and P. Lacasse. 2004. Immune responses to a DNA/protein vaccination strategy against Staphylococcus aureus induced mastitis in dairy cows. Vaccine 23:114-126.

Smith, E. M., L. E. Green, G. F. Medley, H. E. Bird, L. K. Fox, Y. H. Schukken, J. V. Kruze, A. J. Bradley, R. N. Zadoks, and C. G. Dowson. 2005. Multilocus sequence typing of intercontinental bovine Staphylococcus aureus isolates. J. Clin. Microbiol. 43:47374743 .

Steeneveld, W., H. Hogeveen, H. W. Barkema, J. van den Broek, and R. B. M. Huirne. 2008. The influence of cow factors on the incidence of clinical mastitis in dairy cow. J. Dairy Sci. 91:1391-1402.

Stelwagen, K., E. Carpenter, B. Haigh, A. Hodgkinson, and T. T. Wheeler. 2009. Immune components of bovine colostrum and milk. J. Anim. Sci. 87:3-9.

Stoop, W. M., J. A. van Arendonk, J. M. Heck, H. J. van Valenberg, and H. Bovenhuis. 2008. Genetic parameters for major milk fatty acids and milk production traits of Dutch Holstein-Friesians. J. Dairy Sci. 91:385-394.

Svahn, S. L., L. Grahnemo, V. Pálsdóttir, I. Nookaew, K. Wendt, B. Gabrielsson, E. Schéle, A. Benrick, N. Andersson, S. Nilsson, M. E. Johansson, and J. O. Jansson. 2015. Dietary polyunsaturated fatty acids increase survival and decrease bacterial load during septic Staphylococcus aureus infection and improve neutrophil function in mice. Infect. Immun. 83:514-521.

Tollersrud, T., A. H. Kampen, and K. Kenny. 2006. Staphylococcus aureus enterotoxin D is secreted in milk and stimulates specific antibody responses in cows in the course of experimental intramammary infection. Infect. Immun. 74:3507-3512.

Tollersrud, T., L. F. Zernichow, F. A. U. Andersen Sr., K. F. Kenny, and A. Lund. 2001. Staphylococcus aureus capsular polysaccharide type 5 conjugate and whole cell vaccines stimulate antibody responses in cattle. Vaccine 19:3896-3903.

Yang, F. L., C. Shen, B. X. He, Y. Y. Yang, D. C. Gong, and X. S. Li. 2015. The prevalence of heifer mastitis and its associated risk factors in Huanggang, Central China. Trop. Anim. Health Prod. 47:87-92.

Zadoks, R. N., H. G. Allore, H. W. Barkema, O. C. Sampimon, G. J. Wellenberg, Y. T. Gröhn, and Y. H. Schukken. 2001. Cow- and quarter-level risk factors for Streptococcus uberis and Staphylococcus aureus mastitis. J. Dairy Sci. 84:2649-2663.

Zonneveld, M. I., A. R. Brisson, M. J. C. van Herwijnen, S. Tan, C. H. A. van de Lest, F. A. Redegeld, J. Garssen, M. H. M. Wauben, and E. N. M. Nolte-'t Hoen. 2014. Recovery of extracellular vesicles from human breast milk is influenced by sample collection and vesicle isolation procedures. J. Extracell. Vesicles 3:24215. 